\title{
Insulin Stimulates Goose Liver Cell Growth by Activating PI3K-AKT-mTOR Signal Pathway
}

\author{
Chunchun Han ${ }^{a}$ Shouhai Wei ${ }^{b}$ Qi Song ${ }^{a}$ Fang He $^{a}$ Xiangping Xionga \\ Huofu Wan ${ }^{\mathrm{a}}$ Dandan Liu ${ }^{\mathrm{a}}$ Fengjiang Ye ${ }^{\mathrm{a}}$ Hehe Liu ${ }^{\mathrm{a}}$ Liang $\mathrm{Li}^{\mathrm{a}}$ Hongyong $\mathrm{Xu}^{\mathrm{a}}$ \\ Xiaohui Dua Bo Kang ${ }^{a}$ Xianyin Zeng ${ }^{b}$

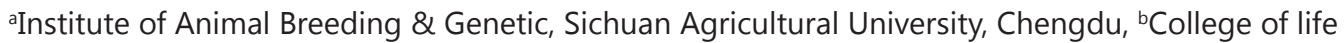 \\ science, Sichuan Agricultural University, Ya'an, P.R. China
}

\section{Key Words}

Insulin • Goose $\cdot$ PI3K-Akt-mTOR signal pathway $•$ Cell proliferation

\begin{abstract}
Background/Aims: Recent studies have suggested a crucial role for PI3K-Akt-mTOR pathway in regulating cell proliferation, so we hypothesize that insulin acts goose hepatocellular growth by PI3K-Akt-mTOR signal pathway. Because the physiological status of liver cells in vitro is different from that in vivo, a simplified cell model in vitro was established. Methods: Goose primary hepatocytes were isolated and incubated in either no addition as a control or insulin or PI3K-Akt-mTOR pathway inhibitors or co-treatment with glucose and PI3K-AktmTOR pathway inhibitors; Then, cell DNA synthesis and cell cycle analysis were detected by BrdU-incorporation Assay and Flow cytometric analysis; the mRNA expression and protein expression of factors involved in the cell cycle were determined by Real-Time RT-PCR, ELISA, and western blot. Results: Here we first showed that insulin evidently increased the cell DNA synthesis, the mRNA level and protein content of factors involved in the cell proliferation of goose primary hepatocytes. Meanwhile, insulin evidently increased the mRNA level and protein content of factors involved in PI3K-Akt-mTOR pathway. However, the up-regulation of insulin on cell proliferation was decreased significantly by the inhibitors of PI3K-Akt-mTOR pathway, LY294002, rapamycin or NVP-BEZ235. Conclusion: These findings suggest that PI3K-Akt-mTOR pathway plays an essential role in insulin-regulated cell proliferation of goose hepatocyte.

\section{Introduction}

As a hormone with a number of biological effects, insulin not only displays the function of classic metabolic regulation, but also can regulate cell proliferation. Administration of insulin to newly hatched chicks improves growth performance via enhancement of cell

C. Han and S. Wei contributed equally to this work.

Chunchun Han

KARGER
Institute of Animal breeding \& Genetic, Sichuan Agricultural University, Chengdu, Sichuan 611130, (P.R. China)

Tel. +86-2886290985, Fax +86-2886291010, E-Mail chunchunhai_510@163.com 


\section{Cellular Physiology Cell Physiol Biochem 2016;38:558-570

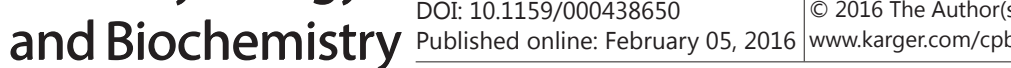 \\ Han et al.: Regulation of Goose Liver Cell Proliferation}

proliferation in chicken myoblasts [1]. Insulin promotes cell growth by the induction of genes involved in cell proliferation [2]. PI3K-Akt-mTOR signal pathway is important for the cell growth and proliferation [3, 4]. As previously discussed, PI3K-Akt-mTOR was required for cell proliferation in different cell types [5, 6]. PI3K-Akt-mTOR pathway is known to play a major regulatory role in insulin pathway [7]. In current study, insulin could promote cell proliferation via PI3K-Akt pathway $[8,9]$. However, there has no report about the role of insulin in cell proliferation of liver cells.

In our previous study, accompanied by the formation of goose hepatic steatosis inducedby overfeeding, plasma insulin increased, and the PI3K-AKT-mTOR signal pathway were activated [10]. It is supposed that in the process of overfeeding to goose, insulin stimulates goose liver cell growth by activating PI3K-AKT-mTOR signal pathway. In order to clarify this hypothesis, in this study, a simplified cell model in vitro was established, for the physiological status of liver cells in vitro is different from that in vivo. We measured whether insulin stimulates the cell proliferation of goose liver cell and the involvement of PI3K-Akt-mTOR pathway in the process is investigated.

\section{Materials and Methods}

\section{Ethical approval}

All procedures performed in studies involving animals were in accordance with the ethical standards of Sichuan Agricultural University at which the studies were conducted.

Primary Hepatocyte Isolation and Culture

Hepatocytes were isolated from three 30-day-old Tianfu meat geese from the Experimental Farm for Waterfowl Breeding at Sichuan Agricultural University using a modification of the "two-step procedure" described by Seglen [11]. The method differed from that of Seglen in that the liver was removed before the preperfusion step. Cultures were incubated at $40^{\circ}$ in a humidified atmosphere containing 5\% CO2; the media was renewed after $3 \mathrm{~h}$, and after $24 \mathrm{~h}$, the media was replaced with serum-free media. After an additional $24 \mathrm{~h}$, the cells were separately treated with serum-free media supplemented with $0,50,100$ and $150 \mu \mathrm{mol} / \mathrm{l}$ of insulin and incubated for $24 \mathrm{~h}$ (the media was not renewed), while the control cells were cultured with serum-free media for $24 \mathrm{~h}$ (serum-free media was not renewed). In addition, some cells were treated with serum-free media supplemented with PI3K-Akt-mTOR pathway inhibitors (LY294002, rapamycin, NVP-BEZ235, respectively) for $24 \mathrm{~h}$ and then added $50 \mathrm{nmol} / \mathrm{L}$ insulin or $150 \mathrm{nmol} / \mathrm{L}$ insulin for the other $24 \mathrm{~h}$ together. After the incubation, the culture media and cells were cooled on ice and collected. In each case, the experiments were repeated three times.

MTT assay for cell viability

The assay for cell viability was performed according to Natali et al. [12], with some modifications. Primary cultures of goose hepatocytes were plated at a density of $0.5 \times 10^{4}$ cells/well in a 96-well culture dish. After the incubation with insulin and inhibitors, the cell monolayers were incubated for $4 \mathrm{~h}$ with 1 $\mathrm{mg} / \mathrm{ml}$ of MTT. The relative cell proliferation ratio was calculated relative to the OD value at $490 \mathrm{~nm}$ of the control group, which was defined as $100 \%$.

\section{Flow cytometric/cell cycle analysis}

The proportion of cells in the G0/G1, S, and G2M phases of the cell cycle was determined by flow cytometric analysis. Primary goose hepatocytes $\left(2 \times 10^{4}\right.$ cells $)$ were plated in 24 -well culture dish. After the incubation with insulin or inhibitors, cells were then harvested by trypsinization, centrifuged at 800 $\mathrm{g}$ for $10 \mathrm{~min}$ and resuspended in a final concentration of $10^{6}$ cells $/ \mathrm{ml}$ in hypotonic propidium iodide (PI) solution. Cells were incubated in $4^{\circ} \mathrm{C}$ for $30 \mathrm{~min}$ and analyzed on a FACScan (Becton-Dickinson, Franklin Lakes, NJ). One hundred thousand cells were collected for each sample. Excitation occurred at $488 \mathrm{~nm}$ and data was collected using the FL2 channel and analyzed using the software modifit. Cell proliferative index $(\mathrm{PI})=(\mathrm{S}+\mathrm{G} 2 \mathrm{M}) /(\mathrm{G} 0 \mathrm{G} 1+\mathrm{S}+\mathrm{G} 2 \mathrm{M}) \times 100$. 


\section{Cellular Physiology Cell Physiol Biochem 2016;38:558-570 \begin{tabular}{ll|l} 
and Biochemistry $10.1159 / 000438650$ & $\begin{array}{l}\text { C 2016 The Author(s). Published by S. Karger AG, Basel } \\
\text { www.karger.com/cpb }\end{array}$ \\
\hline
\end{tabular} Han et al.: Regulation of Goose Liver Cell Proliferation}

BrdU-incorporation Assay

Primary cultures of goose hepatocytes were plated at a density of $0.5 \times 10^{4}$ cells/well in a 96-well culture dish. After the incubation with insulin and inhibitors, cell monolayers were then incubated for $24 \mathrm{~h}$ with $10 \mu \mathrm{M}$ bromodeoxyuridine (BrdU) in culture medium. The cells were then washed and fixed, and the incorporated BrdU was detected by a specific ELISA (Roche, Indianapolis, IN) in an ELISA reader. Meanwhile, the BrdU positive cells were detected. Briefly, after incubation with insulin and inhibitors in $35 \mathrm{~mm}$ culture dishes, the cells were stained with rabbit anti-BrdU antibody (1:100, Beijing Biosynthesis Biotechnology, China), then incubated with goat anti-rabbit Cy3-conjugated secondary antibody (1:300, Beijing Biosynthesis Biotechnology, China), and finally counterstained with DAPI. Cells were visualized using an upright $\mathrm{BH} 2$ microscope (Olympus, Japan) and quantified by counting BrdU-positive cells in 3 independent areas. BrdU-positive cells are green, and the DAPI-positive cells are blue. The experiments were repeated three times.

Measurement of protein content in culture cells

Protein content of relative protein involved in cell proliferation in culture cells were measured using respective ELISA kits according to the manufacturer's instructions. The absorbance at $450 \mathrm{~nm}$ was read using a plate reader. Protein content in the samples were calculated from polynomial second order or exponential standard curves obtained from the standards included in each assay.

\section{Isolation of Total RNA and Real-Time RT-PCR}

Total RNA was isolated from cultured cells using Trizol (Invitrogen, USA) and reverse-transcribed using the Primer Script TM RT system kit for real-time PCR (TaKaRa, Japan) according to the manufacturer's instructions. Specific primers were designed according to the goose gene sequences and are listed in Table 1.

Each sample was repeated in two 96-well plates and the variation of $\mathrm{Ct}$ between the two independent plates was $0.28 \pm 0.22$, showing a fair level of inter-assay reproducibility. PCR products were then diluted 16fold and were used to generate the calibration curve and the amplification rate (R) for each gene. For each experimental sample, a normalized target gene level (Exp), corresponding to the target gene expression level relative to $\beta$-actin, $18 \mathrm{~S}$ and UBC (housekeeping genes) expression levels, was determined by the $2^{-\Delta \Delta \mathrm{Ct}}$ method as previously described [13]:

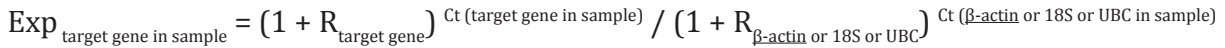

The final results were calculated by extracting the square root of the two relative mRNA levels of each gene relative to $\beta$-actin, 18S and UBC. The results for each individual were repeated three times and averaged.

Protein Analysis by Western Blotting

Total protein extracts were obtained using a reducing SDS buffer. Protein concentrations were determined on diluted samples using a Bradford procedure. Equal amounts of protein $(100 \mu \mathrm{g})$ were separated on a $6 \%$ SDS-PAGE and transferred on membranes. Membranes were blocked in a TBS solution

Table 1. Primer sequences for real-time PCR

\begin{tabular}{|c|c|c|c|c|}
\hline $\begin{array}{l}\text { Gene } \\
\text { Name }\end{array}$ & Upstream $\left(5^{\prime}-3^{\prime}\right)$ & Downstream $\left(5^{\prime}-3^{\prime}\right)$ & $\begin{array}{c}\text { Product size } \\
\text { (bp) }\end{array}$ & $\begin{array}{c}\text { Accession } \\
\text { number }\end{array}$ \\
\hline PI3K & ACCCAAGCGAGGATGAGG & TGTTGCCCGTGTTGAATG & 241 & KF011500 \\
\hline Akt1 & TGCTGGATAAAGATGGAC & CTGGTTGTAGAAAGGGAG & 215 & KF011501 \\
\hline $\mathrm{mTOR}$ & TCATTTGTTACTACCTCCCA & TTTCTAGAGCAGCTTTGCGAGCCAC & 93 & KC424580 \\
\hline S6K & CTCAACTTGCCTCCCTAC & AACTTCTCCAGCATCTCC & 111 & KC424581 \\
\hline 4EBP1 & CCACCTTCTGACCTTCCG & CATTCGCTTTCTCATCGTAG & 103 & KF011497 \\
\hline Rptor & GAAAGGCAAATATCAACCG & CAGCCATCACAGACACCA & 223 & KF011498 \\
\hline P21 & AGGCAACACCTGGAAGAA & ATGAGACCCACCAAGACG & 207 & KC424586 \\
\hline Cyclin D1 & AGGAGCAGAAGTGCGAAGA & TGCGGTCAGAGGAATAGTTT & 158 & KC424583 \\
\hline Cyclin D2 & TTCATCGCCCTTTGTGCC & ATTGCTCCCACGCTTCCA & 80 & KC424584 \\
\hline Cyclin D3 & CTGGTCTCGGTGATAGCG & GACGAAAGTGTAGTCTGTGGC & 135 & KC424585 \\
\hline P27 & CGTAAAGGCGTAGCAGAG & GCAAGTTCCAATCGGTCA & 299 & KF857234 \\
\hline Akt2 & GCGATGCTCCATCACСTCC & CGCCTGCCCTTCTACAACC & 183 & KF857233 \\
\hline UBC & AGGGTGGATTCTTTCTGG & ACTGAGTTTGGAGGGAGC & 243 & GO240773.1 \\
\hline$\beta$-actin & CAACGAGCGGTTCAGGTGT & TGGAGTTGAAGGTGGTCTCG & 92 & M26111.1 \\
\hline $18 \mathrm{~S}$ & TTGGTGGAGCGATTTGTC & ATCTCGGGTGGCTGAACG & 129 & L21170.1 \\
\hline
\end{tabular}




\section{Cellular Physiology Cell Physiol Biochem 2016;38:558-570 \begin{tabular}{ll|l} 
DOI: 10.1159/000438650 & $\begin{array}{l}\text { @ 2016 The Author(s). Published by S. Karger AG, Basel } \\
\text { www.karger.com/cpb }\end{array}$ \\
\hline
\end{tabular} \\ Han et al.: Regulation of Goose Liver Cell Proliferation}

with 5\% nonfat dry milk and incubated with rabbit against Cyclin D1, p21, S6K or p-S6K antibodies (1:1,000; Beijing Biosynthesis Biotechnology, China). A goat anti-rabbit horseradish peroxidase-conjugated IgG at 1:2000 (Beijing Biosynthesis Biotechnology, China) was used as the secondary antibody and the signals were detected using an ECL western blot detection kit (Beyotime Institute of Biotechnology, China). After analysis, the membranes were blotted with $\alpha$-tubulin antibody at 1:1000 (Beijing Biosynthesis Biotechnology, China) to normalize for protein amount. The blot images were digitized with a luminescent image analyzer (LAS1000, Fuji Photo Film).

\section{Statistical Analysis}

The data were subjected to ANOVA testing and the means were assessed for significance by Tukey's test. Analysis of variance and $t$-tests were performed using the SAS 9.13 package (SAS Institute Inc, Cary, $\mathrm{NC}$ ). The results are presented as the mean \pm SD. $\mathrm{P}<0.05$ was accepted as the level of significance. Every experiment was repeated with 3 biological samples, and each sample was run in triplicate.

\section{Results}

Effect of insulin on the cell proliferation of goose hepatocytes

The result of flow cytometric analysis indicated the treatment with insulin stimulated the DNA synthesis in a dose-dependent manner in goose hepatocytes. $100 \mathrm{nM}$ insulin increased DNA synthesis by $26.3 \%$, and $150 \mathrm{nM}$, insulin increased DNA synthesis by $55.5 \%$ (Fig. 1).

The result of BrdU stain (Fig. 2a-c) supported that insulin stimulated cell proliferation. Compared with the control group, the ration of BrdU-positive cells number after the treatment of $150 \mathrm{nmol} / \mathrm{L}$ insulin increased up to 80\% (Fig. 2d). As shown in Fig. 3a, insulin at a concentration of 50,100 or $150 \mathrm{nmol} / \mathrm{L}$ increased the cell viability, and the cell viability showed an upward trend with an increasing insulin concentration. A BrdU incorporation assay was performed to measure the changed DNA synthesis of treated cells (Fig. 3b), and

Fig. 1. Effect of insulin on cell cycle. Goose primary hepatocytes were untreated (a), cultured with $50 \mathrm{nmol} / \mathrm{L}$ insulin (b), 100 $\mathrm{nmol} / \mathrm{L}$ insulin (c), or $150 \mathrm{nmol} / \mathrm{L}$ insulin (d); e, the proportion of cells in the G0/G1, S, and G2M phases of the cell cycle, cell proliferative index $(\mathrm{PI})=(\mathrm{S}+\mathrm{G} 2 \mathrm{M}) /$ $(\mathrm{G} 0 \mathrm{G} 1+\mathrm{S}+\mathrm{G} 2 \mathrm{M}) \times 100$. After $12 \mathrm{~h}$ in serum-free medium, hepatocytes were incubated for $24 \mathrm{~h}$ in either no addition as a control or 50,100 , and $150 \mathrm{nmol} / \mathrm{L}$ insulin. Cells were examined by flow cytometer.

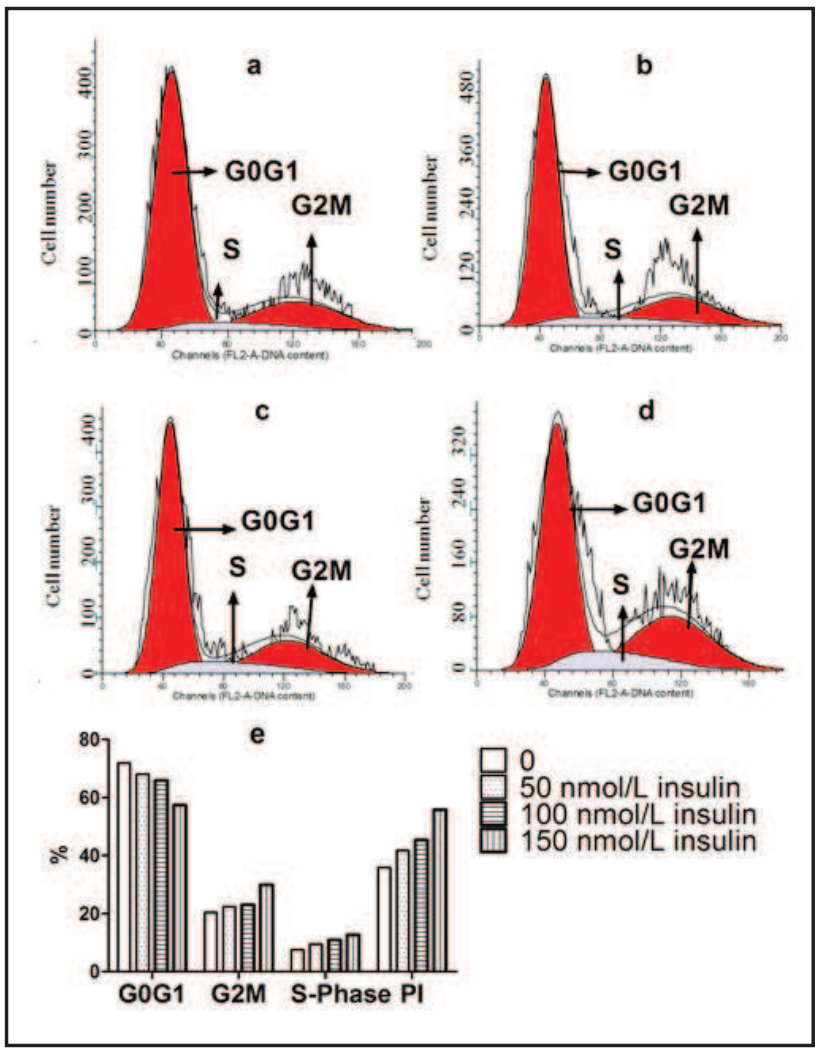




\section{Cellular Physiology Cell Physiol Biochem 2016;38:558-570 \begin{tabular}{ll|l} 
and Biochemistry $10.1159 / 000438650$ & Published online: February 05, 2016 & $\begin{array}{l}\text { (2)16 The Author(s). Published by S. Karger AG, Basel } \\
\text { www.karger.com/cpb }\end{array}$ \\
\hline
\end{tabular} \\ Han et al.: Regulation of Goose Liver Cell Proliferation}

Fig. 2. Effect of insulin on rate of BrdU-positive cells in the goose primary hepatocytes. Goose primary hepatocytes were untreated (a), cultured with $50 \mathrm{nmol} / \mathrm{L}$ insulin (b), or $150 \mathrm{nmol} / \mathrm{L}$ insulin (c). d, Rate of BrdU-positive cells, and results (mean \pm standard error) are expressed as the ratio of the number of BrdU-positive cells compared to the DAPI-positive cells. Different uppercase letters in the same set indicate difference among treatments at $\mathrm{P}<0.05$. Cells were examined by phase contrast microscopy at $200 \times$ magnification.

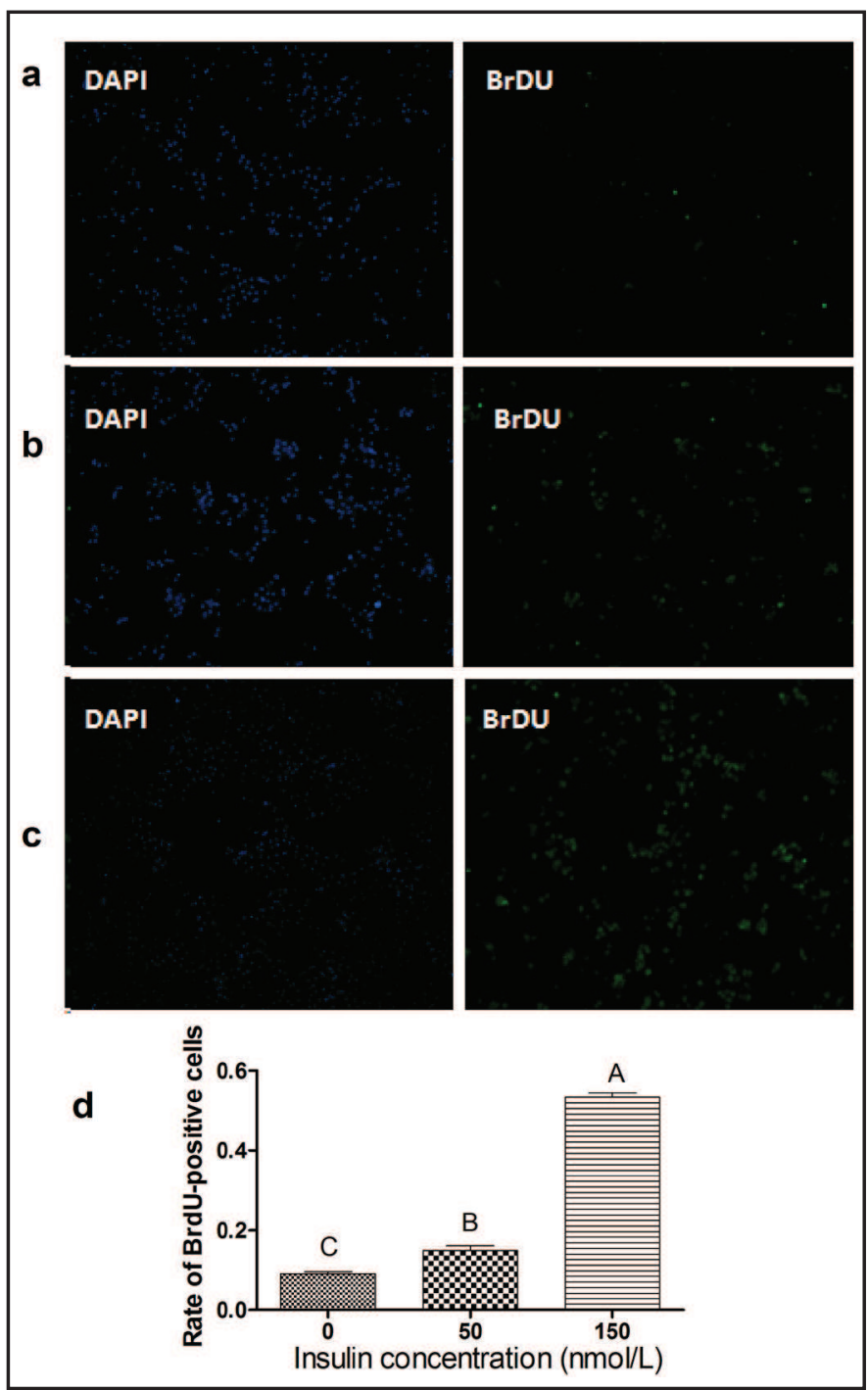

the data indicated the DNA synthesis rate showed an upward trend with an increasing insulin concentration, and it is consistent with the result of BrdU stain.

Fig. 3c and 3d summarized the effect of insulin on protein content of Cyclin D1 and p21. Treatment with 100 and $150 \mathrm{~nm} / \mathrm{L}$ of insulin significantly increased the protein content of Cyclin D1, and significantly decreased the protein content of p21. Fig. 3e and 3f summarized the effect of insulin on mRNA expression level of genes involved in cell proliferation. Compared to the control group, insulin at all three concentrations increased the mRNA level of Cyclin D1, Cyclin D2, Cyclin D3 in a dose-dependent manner. Treatment with 100, and 150 $\mathrm{nm} / \mathrm{L}$ of insulin increased the mRNA level of p21 and p27 significantly. The result of western blot (Fig. 3g) verified that insulin could stimulate the protein expression of Cyclin D1, and inhibit the protein expression of $\mathrm{p} 21$.

LY294002, Rapamycin or NVP-BEZ235 decreased the stimulation of insulin on cell proliferation

To verify that regulation of cell proliferation by insulin is connected to the modulation of PI3K-Akt-mTOR signaling, insulin and a PI3K inhibitor, LY294002, or a mTOR inhibitor, Rapamycin, or a Akt-mTOR dual inhibitor, NVP-BEZ235 were treated together in cell culturement. As shown in Fig. 4a-c, $20 \mu \mathrm{mol} / \mathrm{L}$ LY294002, $30 \mathrm{nmol} / \mathrm{L}$ rapamycin, and 1 $\mu \mathrm{mol} / \mathrm{L}$ NVP-BEZ235 decreased the stimulation of insulin on the DNA synthesis rate of treated cells, and it is consistent with the result of BrdU stain (Fig. 4j) and the result of 


\section{Cellular Physiology \\ Cell Physiol Biochem 2016;38:558-570

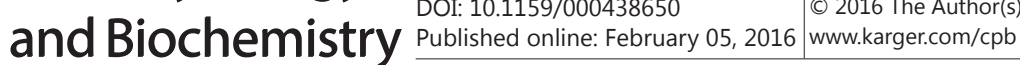 \\ Han et al.: Regulation of Goose Liver Cell Proliferation}

Fig. 3. Stimulator effect of insulin on cell proliferation in the goose primary hepatocytes. (a) Cell viability detected by MTT assay; (b) DNA synthesis rate detected by bromodeoxyuridine incorporation assay; (c and d) Protein content of Cyclin D1 and p21, and the units of Cyclin D1 and $\mathrm{p} 21$ both are $\mathrm{ng} / \mathrm{ml}$; (e and f) Relative mRNA level of genes related with cell proliferation; (g) Western blot result of the protein expression of Cyclin D1 and p21 after insulin treatment. Different uppercase letters in the same set indicate difference among treatments at $\mathrm{P}<0.05$. $\mathrm{OD}=$ optical density.

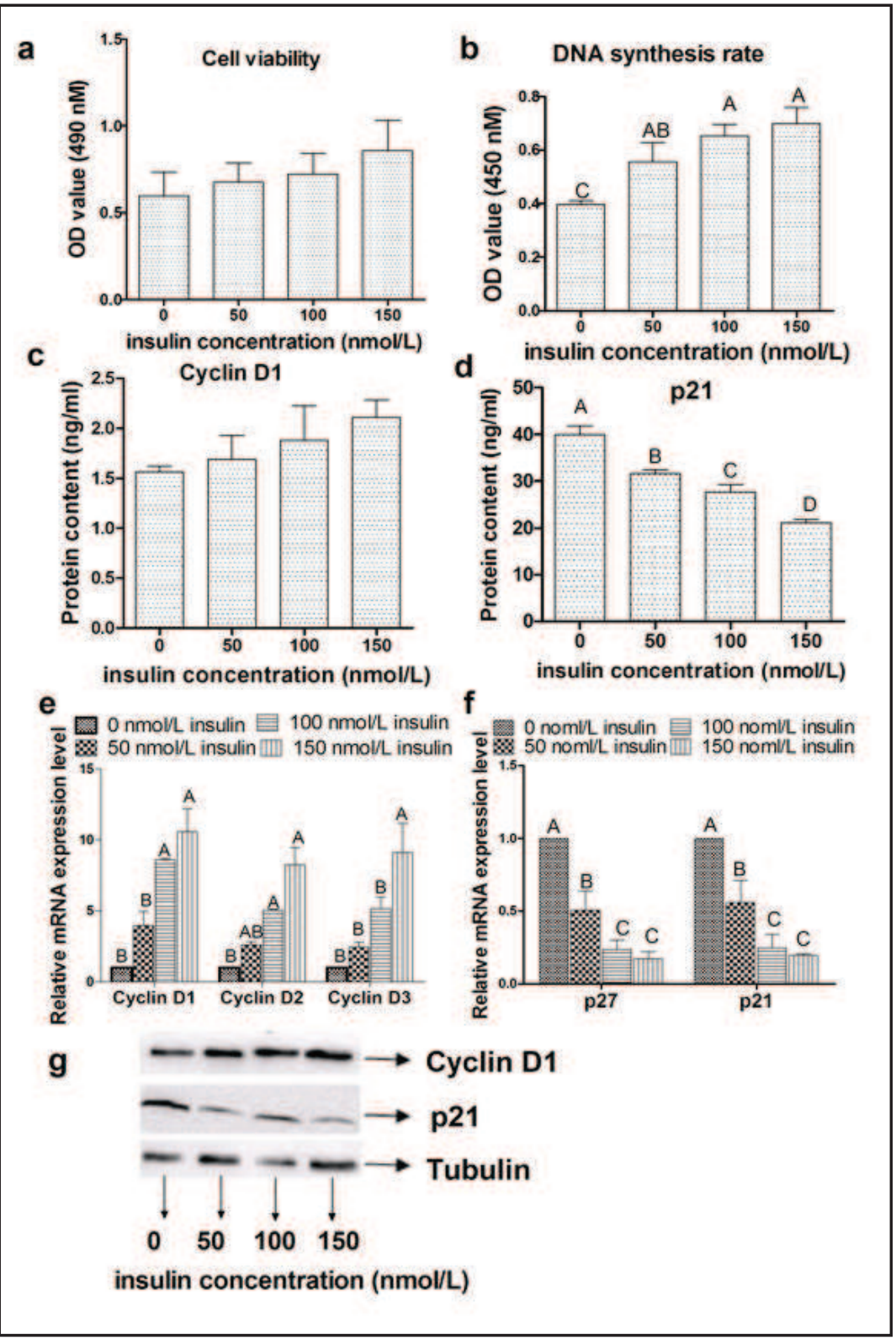

cell cycle analysis (Fig. 5). The result of Fig. 4d-i showed, the protein content of Cyclin D1 after treatment of insulin with $20 \mu \mathrm{mol} / \mathrm{L} \mathrm{LY} 294002$, or $30 \mathrm{nmol} / \mathrm{L}$ rapamycin, or $1 \mu \mathrm{mol} / \mathrm{L}$ NVP-BEZ235 together is lower significantly than that of insulin treatment. Meanwhile, the result of p21 after treatment of insulin with LY294002, rapamycin, or NVP-BEZ235 together is greater significantly than that of insulin treatment. Fig. 6a-c summarized the treatment of LY294002, rapamycin, or NVP-BEZ235 how to affect insulin-induced change on the mRNA expression level of genes involved in cell proliferation. Compared to the insulin treatment, the treatment of insulin at $50 \mathrm{nmol} / \mathrm{L}$ or $150 \mathrm{nmol} / \mathrm{L}$ with LY294002, or rapamycin, or NVPBEZ235 together all decreased the mRNA level of Cyclin D1, Cyclin D2, Cyclin D3, significantly. The mRNA level of p21 and p27 after the treatment of insulin with three inhibitors together are all bigger than that of single insulin treatment significantly. These results indicate that insulin regulate cell proliferation mediated by PI3K-Akt-mTOR signaling pathway. The result of western blot (Fig. 6d) verified that PI3K-Akt-mTOR signaling pathways inhibtors abolished the effect of insulin on the protein expression of Cyclin D1 and p21. 


\section{Cellular Physiology Cell Physiol Biochem 2016;38:558-570 and Biochemistry DOI: 10.1159/000438650 0520102016 The Author(s). Published by S. Karger AG, Basel

Fig. 4. LY294002, Rapamycin or N V P - B E Z 235 decreased the stimulation of insulin on cell proliferation in the goose primary hepatocytes. (a, b and c) DNA synthesis rate detected by bromodeoxyuridine incorporation assay; (d, e, and f) Protein content of Cyclin D1, and the units of Cyclin D1 are $\mathrm{ng} / \mathrm{ml}$; $(\mathrm{g}, \mathrm{h}$, and i) Protein content of p21, and the units of p21 are $\mathrm{ng} / \mathrm{ml}$; "50INS, 150INS, LY, RAP, NVP" under the $\mathrm{X}$ axis indicate the treatment: 50 $\mathrm{nmol} / \mathrm{L}$ insulin, $150 \mathrm{nmol} / \mathrm{L}$ insulin, $20 \mu \mathrm{mol} / \mathrm{L}$ LY294002, 30 nmol/L rapamycin, and $1 \mu \mathrm{mol} / \mathrm{L}$ NVP-BEZ235; (j) rate of BrdU-positive cells, the numbers "1-12" under the $\mathrm{X}$ axis indicate the treatment: 1 , control; 2, $20 \mu \mathrm{mol} / \mathrm{L} \mathrm{LY294002;} \mathrm{3,} 30 \mathrm{nmol} / \mathrm{L}$ rapamycin; 4, $1 \mu \mathrm{mol} / \mathrm{L}$ NVP-BEZ235; 5, $50 \mathrm{nmol} / \mathrm{L}$ insulin, 6, 50 $\mathrm{nmol} / \mathrm{L}$ insulin $+20 \mu \mathrm{mol} / \mathrm{L} \mathrm{LY} 294002 ; 7,50 \mathrm{nmol} / \mathrm{L}$ insulin $+30 \mathrm{nmol} / \mathrm{L} \mathrm{rapamycin;} \mathrm{8,} 50 \mathrm{nmol} / \mathrm{L}$ insulin $+1 \mu \mathrm{mol} / \mathrm{L}$ NVP-BEZ235; 9, $150 \mathrm{nmol} / \mathrm{L}$ insulin; 10, $150 \mathrm{nmol} / \mathrm{L}$ insulin +20 mol/L LY294002; 11, 150 $\mathrm{nmol} / \mathrm{L}$ insulin $+30 \mathrm{nmol} / \mathrm{L}$ rapamycin; $12,150 \mathrm{nmol} / \mathrm{L}$ insulin $+1 \mu \mathrm{mol} / \mathrm{L}$ NVP-BEZ23550. Different uppercase letters in the same set indicate difference among treatments at $\mathrm{P}<0.05 . \mathrm{OD}=$ optical density.

\section{Insulin stimulate PI3K-Akt-mTOR pathway}

Fig. 7a summarized the effect of insulin on mRNA expression level of genes involved in PI3K-Akt-mTOR pathway. Compared to the control group, insulin at all three concentrations increased the mRNA level of PI3K, Akt1, Akt2, mTOR, Rptor, 4EBP1, and S6K in a dosedependent manner. Fig. $7 \mathrm{~b}$ showed, treatment with 100 or $150 \mathrm{~nm} / \mathrm{l}$ of insulin significantly increase the protein content of PI3K, Akt, mTOR, 4EBP1, and S6K. The result of western blot in Fig. 7c showed insulin stimulated of the protein expression of S6K and p-S6K. These results indicate that insulin treatment could stimulate PI3K-Akt-mTOR signaling pathways. 


\section{Cellular Physiology Cell Physiol Biochem 2016;38:558-570

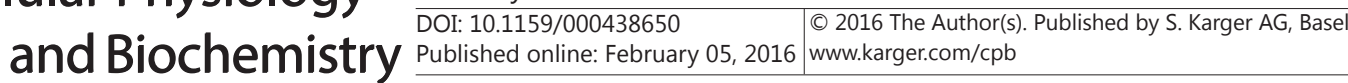 \\ Han et al.: Regulation of Goose Liver Cell Proliferation}

Fig. 5. LY294002, Rapamycin or NVPBEZ235 decreased the stimulation of insulin on cell cycle in the goose primary hepatocytes. Goose primary hepatocytes were untreated (a), cultured with $50 \mathrm{nmol} / \mathrm{L}$ insulin (b), $20 \mu \mathrm{mol} / \mathrm{L}$ LY294002 (c), $50 \mathrm{nmol} / \mathrm{L}$ insulin + $20 \mu \mathrm{mol} / \mathrm{L} \mathrm{LY} 294002$ (d), $30 \mathrm{nmol} / \mathrm{L}$ rapamycin (e), $50 \mathrm{nmol} / \mathrm{L}$ insulin + $30 \mathrm{nmol} / \mathrm{L}$ rapamycin (f), $1 \mu \mathrm{mol} / \mathrm{L}$ NVP-BEZ235 (g),50 nmol/L insulin + $1 \mu \mathrm{mol} / \mathrm{L}$ NVP-BEZ235 (h). Cells were examined by flow cytometer.

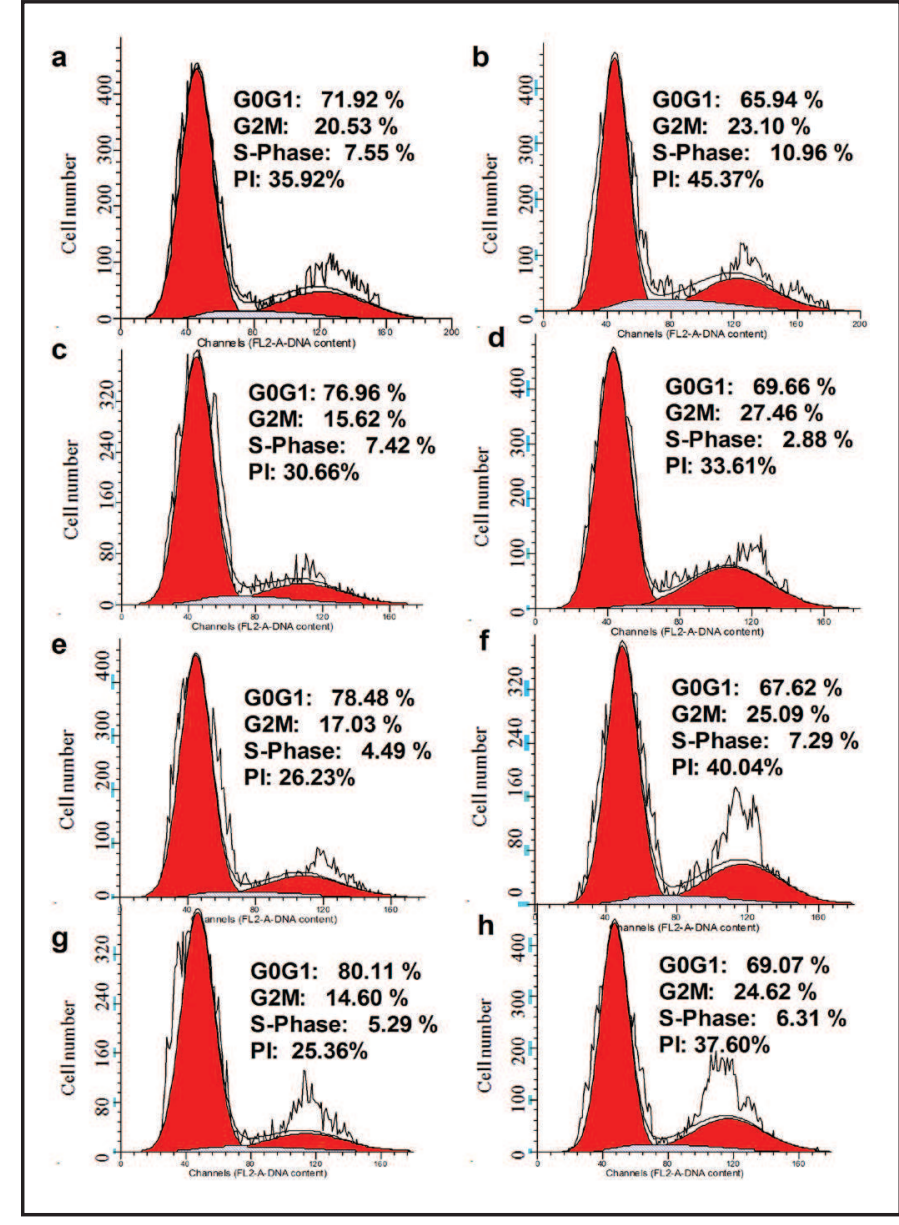

LY294002, Rapamycin or NVP-BEZ235 decreased the stimulation of insulin on PI3K-AktmTOR signal pathway

To further verify that activation of PI3K-Akt-mTOR signal pathway by insulin, the collective effect of insulin and PI3K-Akt-mTOR signal pathway inhibitors on the protein content and mRNA level of PI3K-Akt-mTOR signal pathway was assessed. As shown in Fig. 8a-e, after collective treatment with insulin and $20 \mu \mathrm{mol} / \mathrm{L} \mathrm{LY294002,30} \mathrm{nmol/L}$ rapamycin, and $1 \mu \mathrm{mol} / \mathrm{L}$ NVP-BEZ235, the protein content of PI3K, Akt, mTOR, 4EBP1, and S6K is lower than that after single insulin treatment. The result of western blot in Fig. $8 \mathrm{f}$ showed that, compared with the stimulation role of insulin alone, the collective treatment of insulin at $150 \mathrm{nmol} / \mathrm{L}$ with $20 \mu \mathrm{mol} / \mathrm{L} \mathrm{LY294002,} \mathrm{or} 30 \mathrm{nmol} / \mathrm{L} \mathrm{rapamycin,} \mathrm{or} 1 \mu \mathrm{mol} / \mathrm{L}$ NVP-BEZ235 decreased the protein expression level of S6K and p-S6K. Fig. 9 summarized the three PI3K-Akt-mTOR signal pathway inhibitors decreased the activation of insulin on the mRNA expression level of genes involved in PI3K-Akt-mTOR pathway. Compared to the result of insulin treatment, the mRNA level of PI3K, Akt1, Akt2, mTOR, Rptor, 4EBP1, and S6K all decreased, significantly after the collective treatment of insulin at $50 \mathrm{nmol} / \mathrm{l}$ or 150 nmol/L with $20 \mu \mathrm{mol} / \mathrm{L}$ LY294002, or $30 \mathrm{nmol} / \mathrm{L}$ rapamycin, or $1 \mu \mathrm{mol} / \mathrm{L}$ NVP-BEZ235. These results further verify that the activation role of insulin in cell proliferation is mediated by PI3K-Akt-mTOR signaling pathways.

\section{Discussion}

Previous research has already demonstrated insulin play a role in overfeeding-induced goose fatty liver and hepatic lipids deposition $[14,15]$. However, whether insulin regulates 


\section{Cellular Physiology Cell Physiol Biochem 2016;38:558-570

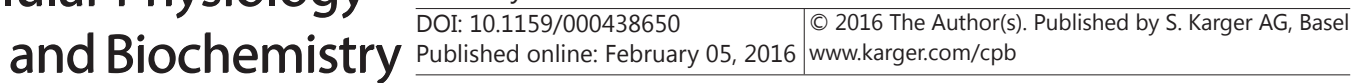 \\ Han et al.: Regulation of Goose Liver Cell Proliferation}

Fig. 6. LY294002, Rapamycin or NVPBEZ235 decreased the stimulation of insulin on relative mRNA level and protein expression of genes related with cell proliferation. (a) relative mRNA level after treatment of LY294002 and insulin together or alone; (b) relative mRNA level after treatment of Rapamycin and insulin together or alone; (c) relative mRNA level after treatment of NVPBEZ235 and insulin together or alone; Different uppercase letters in the same set indicate difference among treatments at $\mathrm{P}<0.05$; (d) Western blot result of the protein expression of Cyclin D1 and p21 after the treatment of insulin and LY294002, Rapamycin or NVPBEZ235 together or
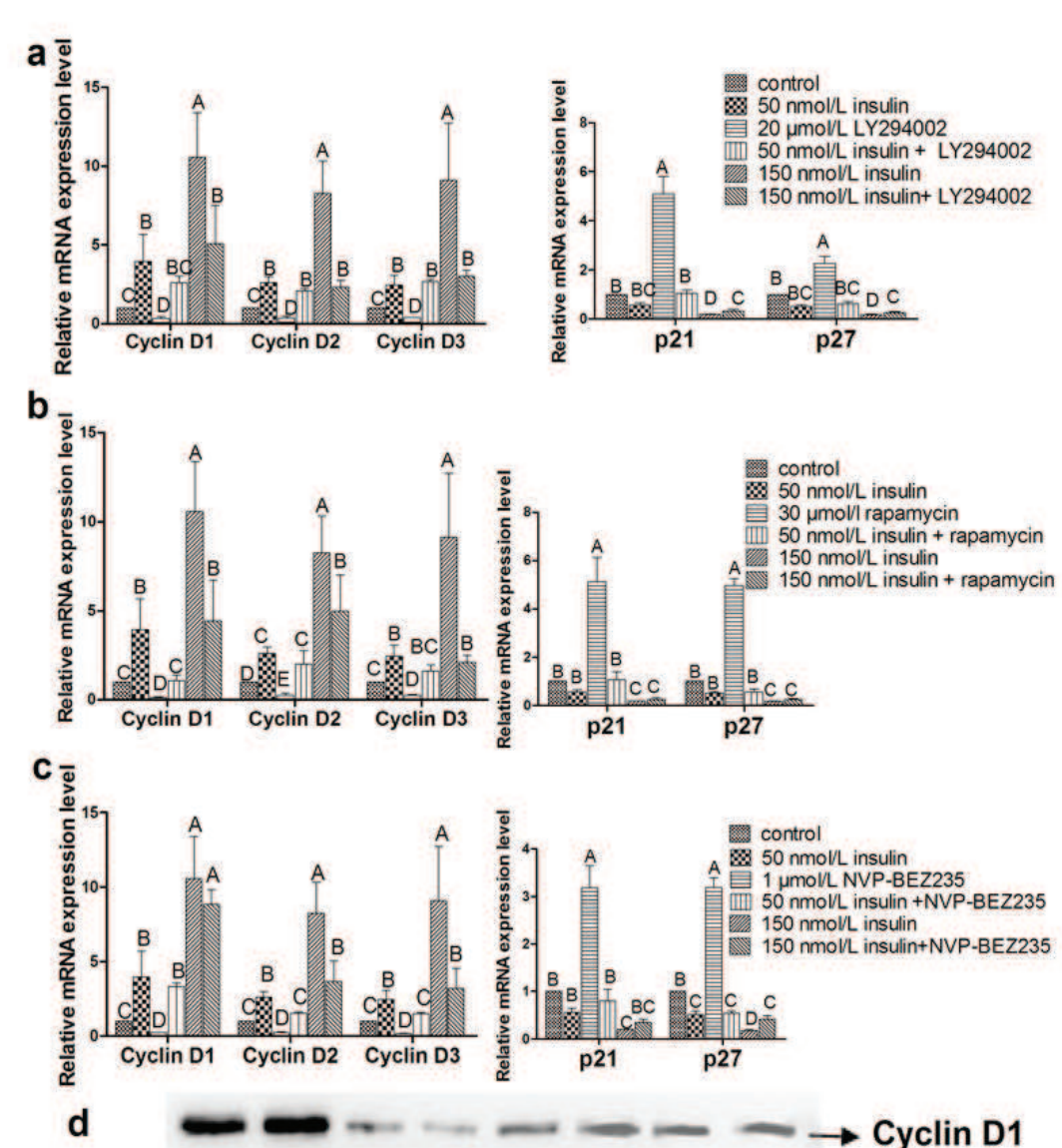

alone. The numbers "1, 2, 3, 4, 5, 6, 7, 8" under the blot indicate control, $150 \mathrm{nmol} / \mathrm{L}$ insulin, $20 \mu \mathrm{mol} / \mathrm{L}$

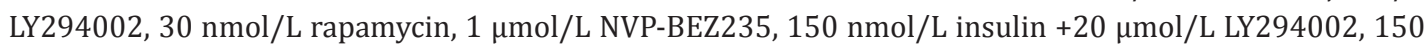
$\mathrm{nmol} / \mathrm{L}$ insulin $+30 \mathrm{nmol} / \mathrm{L}$ rapamycin, and $150 \mathrm{nmol} / \mathrm{L}$ insulin $+1 \mu \mathrm{mol} / \mathrm{L}$ NVP-BEZ235, respectively. Each blot is a representative of three independent experiments.

the cell growth of goose liver is unclear. In this study we demonstrated that insulin promoted an increase in proliferation of goose hepatocytes at 50,100 and $150 \mathrm{nmol} / \mathrm{L}$, respectively. Such doses are much higher than physiological concentration of insulin (0.1-1 nmol/L). Similar comparable does-dependent growth response to insulin has been observed in other cell lines such as MCF- 7 breast cancer cells [16]. After culture with three PI3K-Akt-mTOR pathway inhibitors, LY294002, Rapamycin, or NVPBEZ235, the cell proliferation was inhibited. The inhibiting role of NVPBEZ235 was evident than that of LY294002 and rapamycin. When PI3KAkt-mTOR pathway was blocked by LY294002, Rapamycin, or NVPBEZ235, respectively, insulin still promoted cell growth as compared to the cells treated with inhibitor alone, but its effect was lower than the insulin treatment alone. Cell proliferation driven by insulin was effectively reverted using the dual PI3K/mTOR inhibitor, NVP-BEZ235, both in vitro and in vivo [17]. We further found that when PI3K was blocked by LY294002, insulin still increased 


\section{Cellular Physiology \\ Cell Physiol Biochem 2016;38:558-570 \\ \begin{tabular}{l|l}
\hline DOI: $10.1159 / 000438650$ & C 2016 The Author(s). Published by S. Karger AG, Basel
\end{tabular} and Biochemistry Published online: February 05, 2016 www.kargercom/cpb \\ Han et al.: Regulation of Goose Liver Cell Proliferation}

Fig. 7. Treatment with insulin stimulate PI3K-Akt-mTOR pathway. (a) Relative mRNA level of genes related with PI3K-AktmTOR pathway; (b) Protein content of factors involved in PI3K-Akt-mTOR pathway, and the unit of PI3K is $\mathrm{pmol} / \mathrm{ml}$, the units of Akt1 and mTOR are pg/ $\mathrm{ml}$, the units of S6K and4EBP1 are ng/ml; (c) Result of western blot for S6K and p-S6K. Each blot is a representative of three independent experiments. Different uppercase letters in the same set indicate difference among treatments at $\mathrm{P}<0.05$.

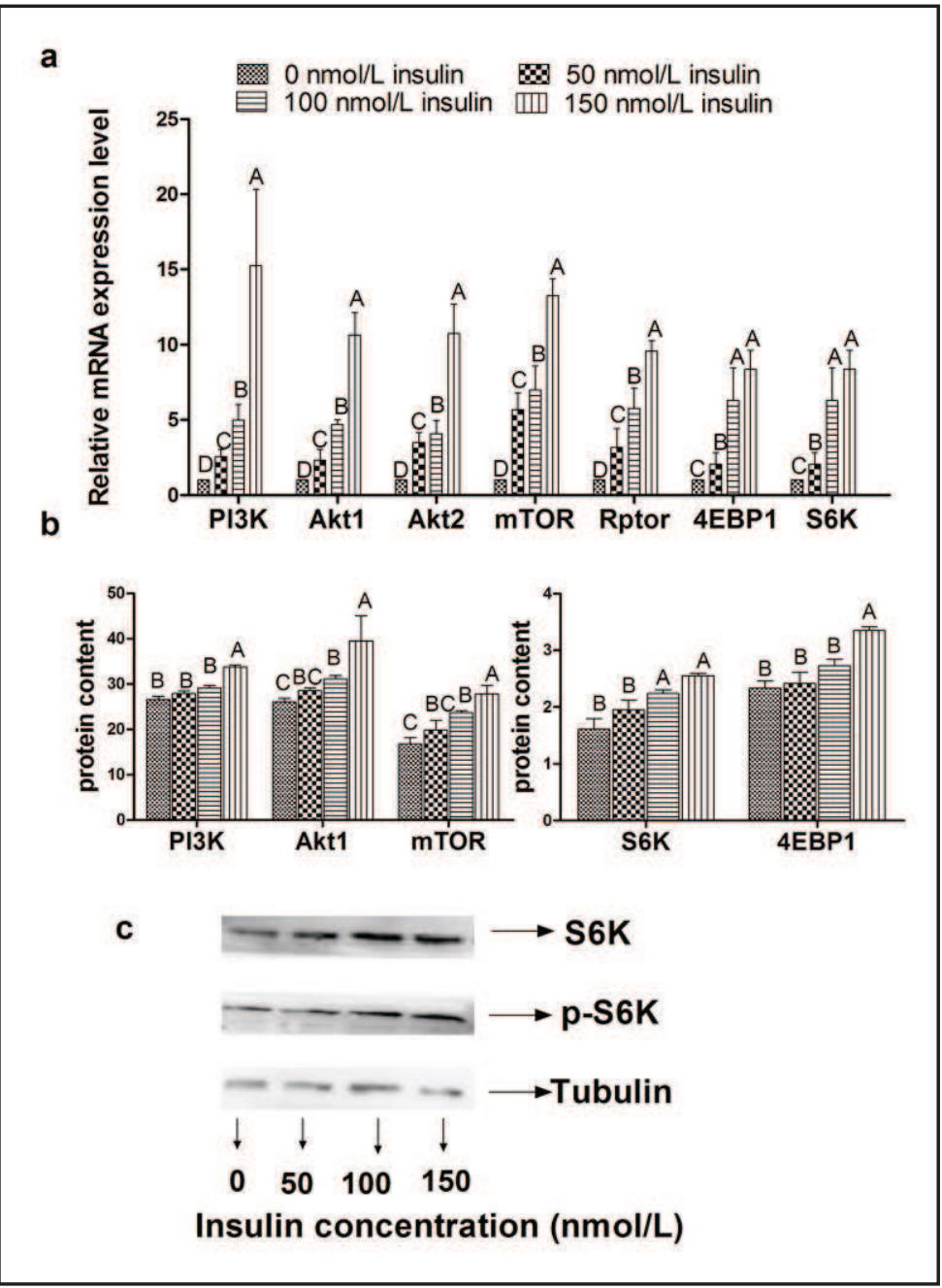

the gene expression and activity of PI3K downstream targets Akt and mTOR. These results suggested that alternative pathways to the activation of Akt and mTOR might be involved in insulin-induced cell proliferation.

mTOR is a downstream target of Akt. Interestingly, rapamycin inhibited the mRNA and activity of mTOR, but also inhibited the mRNA and activity of PI3K and Akt. However, in other reports, rapamycin inhibits mTOR, and it can lead to activation of upstream proteins such as Akt, due to the loss of a feedback loop mechanism $[18,19]$. The reason why rapamycin inhibited PI3K and Akt in goose liver cells remains to be determined. mTOR seems to be involved only partly in the insulin action on cell proliferation, because the inhibition of mTOR by rapamycin did not completely abolish insulin-induced cell proliferation. These results suggest that at least the two following pathways are involved in insulin-induced cell proliferation regulation, a PI3K-Akt-dependent/mTOR-independent pathway and a PI3KAkt/mTOR-dependent pathway. It has been shown that insulin could revert the inhibition of the dual PI3K/mTOR inhibitor NVPBEZ235 induced-decrease of cell proliferation in goose. Insulin increased the levels of phosphorylated mTOR and p-S6K in parental HepG2 cells and HepG2 cells overexpressing constitutively active Akt/PKB cell lines. Rapamycin treatment partially decreased the phosphorylation of mTOR but completely abolished the phosphorylation of p-S6K in the absence as well as presence of insulin in both cell lines [20]. In this study, rapamycin caused inhibition of cell proliferation both in the absence and presence of insulin, but the inhibitory effect was reverted evidently in the absence of insulin. It is possible that the presence of insulin might lead to phosphorylation of $\mathrm{p}-\mathrm{S} 6 \mathrm{~K}$ and/or 


\section{Cellular Physiology \\ Cell Physiol Biochem 2016;38:558-570

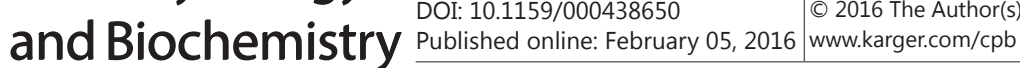 \\ Han et al.: Regulation of Goose Liver Cell Proliferation}

Fig. 8. LY294002, Rapamycin or NVP-BEZ235 decreased the stimulation of insulin on the protein level of factors involved in PI3K-Akt-mTOR signal pathway. (a - e) Protein content of factors involved in PI3K-Akt-mTOR pathway, and the unit of PI3K is $\mathrm{pmol} / \mathrm{ml}$, the units of Akt1 and $\mathrm{mTOR}$ are $\mathrm{pg} / \mathrm{ml}$, the units of S6K and 4EBP1 are $\mathrm{ng} / \mathrm{ml}$. The numbers “ $1,2,3,4,5,6,7,8,9,10$, 11,12 " under the $\mathrm{X}$ axis indicate control, $20 \mu \mathrm{mol} / \mathrm{L}$ LY294002, $30 \mathrm{nmol} / \mathrm{L}$ rapamycin, $1 \mu \mathrm{mol} / \mathrm{L}$ NVPBEZ235, $50 \mathrm{nmol} / \mathrm{L}$ insulin, $50 \mathrm{nmol} / \mathrm{L}$ insulin +20 $\mu \mathrm{mol} / \mathrm{L}$ LY294002, $50 \mathrm{nmol} / \mathrm{L}$ insulin +30 $\mathrm{nmol} / \mathrm{L}$ rapamycin, 50 $\mathrm{nmol} / \mathrm{L}$ insulin $+1 \mu \mathrm{mol} / \mathrm{L}$ NVP-BEZ235, $150 \mathrm{nmol} / \mathrm{L}$ insulin, $150 \mathrm{nmol} / \mathrm{L}$ insulin $+20 \mu \mathrm{mol} / \mathrm{L} \mathrm{LY294002,}$ $150 \mathrm{nmol} / \mathrm{L}$ insulin +30 $\mathrm{nmol} / \mathrm{L}$ rapamycin, and $150 \mathrm{nmol} / \mathrm{L}$ insulin +1 $\mu \mathrm{mol} / \mathrm{L}$ NVP-BEZ235, respectively; (f) Western blot result of the protein expression of $\mathrm{S} 6 \mathrm{~K}$ and p-S6K after the treatment of insulin and LY294002,

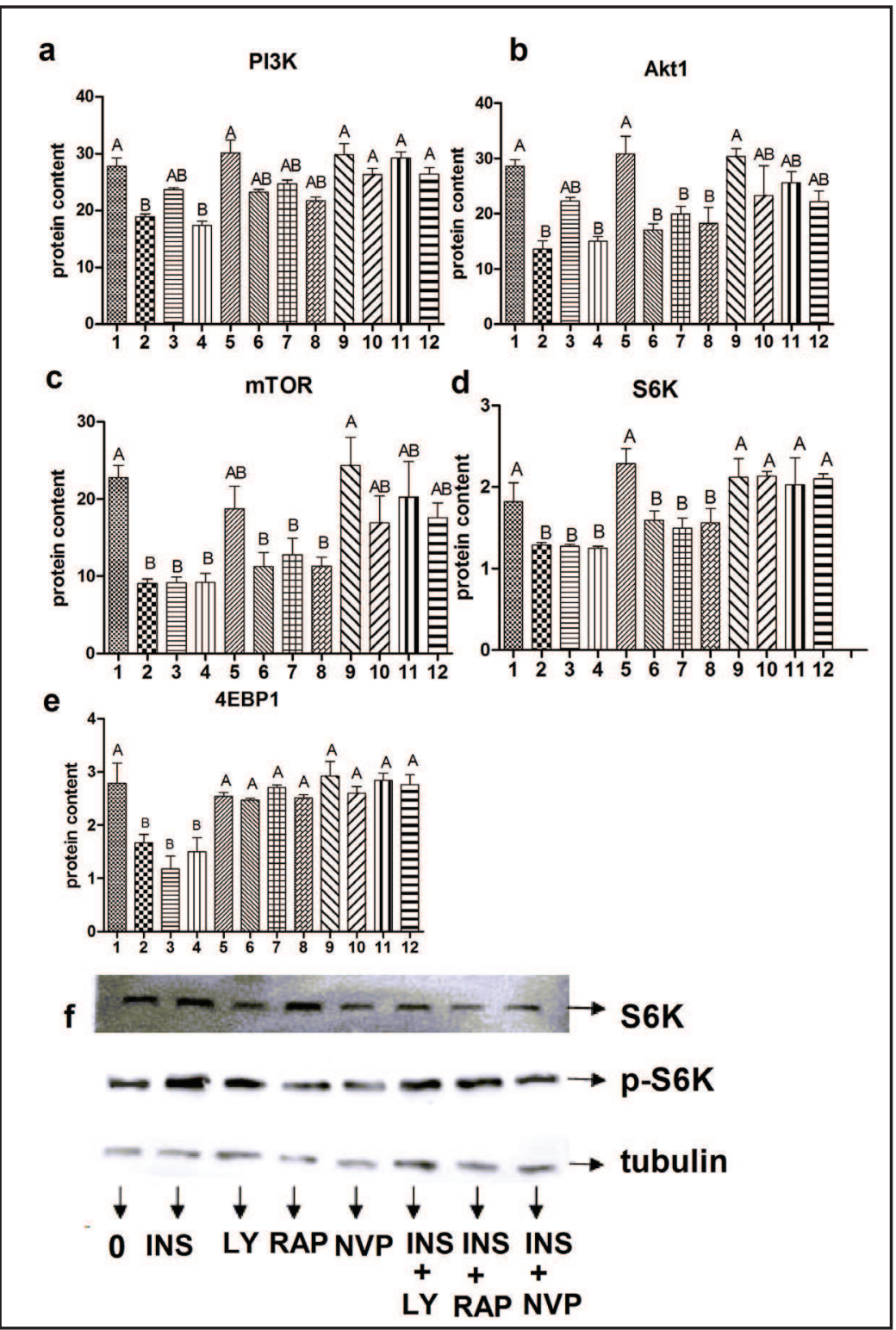

Rapamycin or NVP-BEZ235 together or alone. "INS, LY, RAP, NVP" under the blot indicate $150 \mathrm{nmol} / \mathrm{L}$ insu-

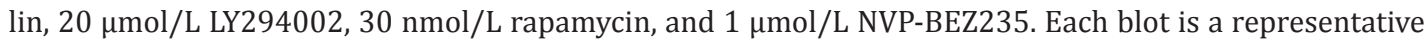
of three independent experiments.

reversal of mTOR activity even in the presence of rapamycin and this might be the cause of cell proliferation even in the presence of rapamycin. Alternatively, there may be other kinases controlling the activated cell proliferation, although the dual PI3K/mTOR inhibitor NVPBEZ235 was applied in these cells.

Insulin activated the mRNA level or protein content of cyclin D1, cyclin D2, and cyclin D3, three critical regulators of cell proliferation, and it inhibited the mRNA level or protein content of p21 and p27, two cell cycle inhibitors. Meanwhile, insulin stimulated the mRNA level and protein content of genes involved in the PI3K-Akt-mTOR pathway. The culture with three PI3K-Akt-mTOR pathway inhibitors, LY294002, Rapamycin, or NVPBEZ235, decreased the mRNA level or protein content of Cyclin D1, Cyclin D2, and Cyclin D3, increased the mRNA level or protein content of p21 and p27. However, after the treatment of LY294002, Rapamycin, or NVPBEZ235, insulin could restore the mRNA level or protein content of relative factors, which means insulin could stimulate cell proliferation mediated-by PI3K- 


\section{Cellular Physiology \\ Cell Physiol Biochem 2016;38:558-570 \\ \begin{tabular}{l|l}
\hline DOI: $10.1159 / 000438650$ & C 2016 The Author(s). Published by S. Karger AG, Basel
\end{tabular} and Biochemistry Published online: February 05, 2016 www.karger.com/cpb \\ Han et al.: Regulation of Goose Liver Cell Proliferation}

Fig. 9. LY294002, Rapamycin or NVPBEZ235 decreased the stimulation of insulin on relative mRNA level of genes related with PI3K-Akt-mTOR pathway. Different uppercase letters in the same set indicate difference among treatments at $\mathrm{P}<0.05$. The numbers " $1,2,3,4,5,6,7,8$, $9,10,11,12$ " under the $\mathrm{X}$ axis indicate

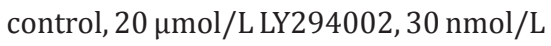
rapamycin, $1 \mu \mathrm{mol} / \mathrm{L}$ NVP-BEZ235, 50 $\mathrm{nmol} / \mathrm{L}$ insulin, $50 \mathrm{nmol} / \mathrm{L}$ insulin +20 $\mu \mathrm{mol} / \mathrm{L}$ LY294002, $50 \mathrm{nmol} / \mathrm{L}$ insulin $+30 \mathrm{nmol} / \mathrm{L}$ rapamycin, $50 \mathrm{nmol} / \mathrm{L}$ insulin $+1 \mu \mathrm{mol} / \mathrm{L}$ NVP-BEZ235, 150 $\mathrm{nmol} / \mathrm{L}$ insulin, $150 \mathrm{nmol} / \mathrm{L}$ insulin +20 $\mu \mathrm{mol} / \mathrm{L}$ LY294002, $150 \mathrm{nmol} / \mathrm{L}$ insulin +30 nmol/L rapamycin, and $150 \mathrm{nmol} / \mathrm{L}$ insulin $+1 \mu \mathrm{mol} / \mathrm{L}$ NVP-BEZ235, respectively.

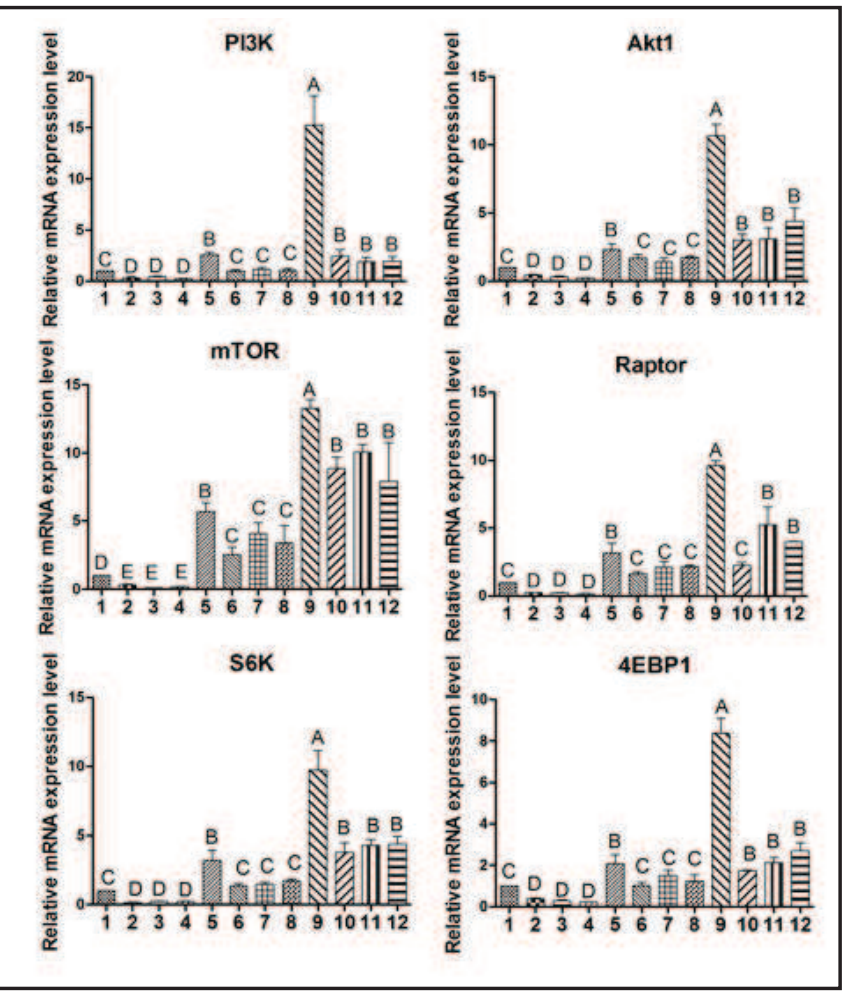

Akt-mTOR pathway, and cyclin D family played an important role. Reports said the mice or MIN6 cells overexpressing a constitutively active form of Akt showed enhanced beta cell proliferation that is associated with increased protein levels of cyclin D family and p21 [21, 22]. Our result indicated p21 played an inhibiting role in insulin-stimulated cell proliferation, but the experiments in p21 deficient mice have demonstrated that p21 is not essential for maintaining beta cell function and cell cycle arrest in vivo [23]. In contrast, transgenic mice overexpressing p21 show decreased beta cell replication [24]. Thus, the mechanisms of p21 involved in the regulation of cell proliferation are different in different cell types.

In summary, our data demonstrated that insulin promoted cell proliferation. PI3Kindependent activation of Akt might contribute to the cell proliferation of insulin on goose primary hepatocytes. And at least the two following pathways are involved in insulininduced cell proliferation regulation, a PI3K-Akt-dependent/mTOR-independent pathway and a PI3K-Akt-mTOR -dependent pathway.

\section{Acknowledgments}

The work was supported by the National Natural Science Funds of China (No. 31101712), and the Research Fund for the Doctoral Program of Higher Education of China (No.20115103120006).

\section{Disclosure Statement}

The authors declare that they have no conflict of interest.

\section{References}

1 Sato K, Aoki M, Kondo R, Matsushita K, Akiba Y, Kamada T: Administration of insulin to newly hatched chicks improves growth performance via impairment of MyoD gene expression and enhancement of cell proliferation in chicken myoblasts. Gen Comp Endocrinol 2012;175:457-463. 


\section{Cellular Physiology Cell Physiol Biochem 2016;38:558-570 \begin{tabular}{ll|l} 
and Biochemistry & Dublished online: February 05, 2016 & $\begin{array}{l}\text { @ } 2016 \text { The Author(s). Published by S. Karger AG, Basel } \\
\text { www.karger.com/cpb }\end{array}$ \\
\hline
\end{tabular} \\ Han et al.: Regulation of Goose Liver Cell Proliferation}

2 Kido Y, Nakae J, Accili D: The insulin receptor and its cellular targets1. J Clin Endocr Metab 2001;86:972979.

3 Chang F, Lee JT, Navolanic PM, Steelman LS, Shelton JG, Blalock WL, Franklin RA, McCubrey JA: Involvement of PI3K/Akt pathway in cell cycle progression, apoptosis, and neoplastic transformation: A target for cancer chemotherapy. Leukemia 2003;17:590-603.

$4 \quad$ Wullschleger S, Loewith R, Hall MN: TOR signaling in growth and metabolism. Cell 2006;124:471-484.

5 Pellegatta F, Chierchia SL, Zocchi MR: Functional association of platelet endothelial cell adhesion molecule-1 and phosphoinositide 3-kinase in human neutrophils. J Biol Chem 1998;273:27768-27771.

6 Barquilla A, Crespo JL, Navarro M: Rapamycin inhibits trypanosome cell growth by preventing TOR complex 2 formation. Proc Natl Acad Sci U S A 2008;105:14579-14584.

7 Qiang G, Yang X, Shi L, Zhang H, Chen B, Zhao Y, Zu M, Zhou D, Guo J, Yang H, Zhang L, Du G: Antidiabetic Effect of Salvianolic Acid a on Diabetic Animal Models via AMPK Activation and Mitochondrial Regulation. Cell Physiol Biochem 2015;36:395-408.

8 Li Q, Li G, Lan X, Zheng M, Chen KH, Cao CM, Xiao RP: Receptor interacting protein 3 suppresses vascular smooth muscle cell growth by inhibition of the phosphoinositide 3-kinase-Akt axis. J Biol Chem 2010;285:9535-9544.

9 Liu S, Li Y, Lin T, Fan X, Liang Y, Heemann U: High dose human insulin and insulin glargine promote T24 bladder cancer cell proliferation via PI3K-independent activation of Akt. Diabetes Res Clin Pract 2011;91:177-182.

10 Han C, Ye F, Shen X, Liu D, He F, Wei S, Xu H, Li L, Liu H: Change of the mTOR pathway in tissues of overfed geese. Braz J Poult Sci 2015;17:293-299.

11 Seglen PO: Preparation of isolated rat liver cells. Methods Cell Biol 1976;13:29-83.

12 Natali F, Siculella L, Salvati S, Gnoni GV: Oleic acid is a potent inhibitor of fatty acid and cholesterol synthesis in C6 glioma cells. J Lipid Res 2007;48:1966-1975.

13 Livak KJ, Schmittgen TD: Analysis of relative gene expression data using real-time quantitative PCR and the 2(-Delta Delta C(T)) Method. Methods 2001;25:402-408.

14 Han C, Wang J, Xu H, Li L, Ye J, Jiang L, Zhuo W: Effect of overfeeding on plasma parameters and mRNA expression of genes associated with hepatic lipogenesis in geese. Asian Austral J Anim 2008;21:590-595.

15 Han C, Wei S, He F, Liu D, Wan H, Liu H, Li L, Xu H, Du X, Xu F: The regulation of lipid deposition by insulin in goose liver cells is mediated by the PI3K-AKT-mTOR signaling pathway. PLoS ONE 2015;10:e98759.

16 Staiger K, Hennige AM, Staiger H, Haring HU, Kellerer M: Comparison of the mitogenic potency of regular human insulin and its analogue glargine in normal and transformed human breast epithelial cells. Horm Metab Res 2007;39:65-67.

17 Evert M, Calvisi DF, Evert K, De Murtas V, Gasparetti G, Mattu S, Destefanis G, Ladu S, Zimmermann A, Delogu S, Thiel S, Thiele A, Ribback S, Dombrowski F: V-AKT murine thymoma viral oncogene homolog/ mammalian target of rapamycin activation induces a module of metabolic changes contributing to growth in insulin-induced hepatocarcinogenesis. Hepatology 2012;55:1473-1484.

18 Harrington LS, Findlay GM, Gray A, Tolkacheva T, Wigfield S, Rebholz H, Barnett J, Leslie NR, Cheng S, Shepherd PR, Gout I, Downes CP, Lamb RF: The TSC1-2 tumor suppressor controls insulin-PI3K signaling via regulation of IRS proteins. J Cell Biol 2004;166:213-223.

19 Zhang H, Cicchetti G, Onda H, Koon HB, Asrican K, Bajraszewski N, Vazquez F, Carpenter CL, Kwiatkowski DJ: Loss of Tsc1/Tsc2 activates mTOR and disrupts PI3K-Akt signaling through downregulation of PDGFR. J Clin Invest 2003;112:1223-1233.

20 Varma S, Khandelwal RL: Effects of rapamycin on cell proliferation and phosphorylation of mTOR and p70(S6K) in HepG2 and HepG2 cells overexpressing constitutively active Akt/PKB. Biochim Biophys Acta 2007;1770:71-78.

21 Blandino-Rosano M, Alejandro EU, Sathyamurthy A, Scheys JO, Gregg B, Chen AY, Rachdi L, Weiss A, Barker DJ, Gould AP, Elghazi L, Bernal-Mizrachi E: Enhanced beta cell proliferation in mice overexpressing a constitutively active form of Akt and one allele of p21Cip. Diabetologia 2012;55:1380-1389.

22 Balcazar N, Sathyamurthy A, Elghazi L, Gould A, Weiss A, Shiojima I, Walsh K, Bernal-Mizrachi E: MTORC1 activation regulates beta-cell mass and proliferation by modulation of cyclin D2 synthesis and stability. J Biol Chem 2009;284:7832-7842.

23 Cozar-Castellano I, Weinstock M, Haught M, Velazquez-Garcia S, Sipula D, Stewart AF: Evaluation of betacell replication in mice transgenic for hepatocyte growth factor and placental lactogen: Comprehensive characterization of the G1/S regulatory proteins reveals unique involvement of p21cip. Diabetes 2006;55:70-77.

24 Yang J, Zhang W, Jiang W, Sun X, Han Y, Ding M, Shi Y, Deng H: P21cip-overexpression in the mouse beta cells leads to the improved recovery from streptozotocin-induced diabetes. PLoS ONE 2009;4:e8344. 